\title{
Abdominal Angiostrongylosis in Southern Brazil - Prevalence and Parasitic Burden in Mollusc Intermediate Hosts from Eighteen Endemic Foci
}

\author{
Paulo R Rambo, Aventino A Agostini*, Carlos Graeff-Teixeira/ ${ }^{+}$ \\ Laboratório de Parasitologia, Departamento de Ciências Microbiológicas e Curso de Pós-Graduação em \\ Biociências, Instituto de Biociências, PUCRS, Av. Ipiranga 6681, 90619-900 Porto Alegre, RS, Brasil \\ *Disciplina de Anatomia Patológica, Departamento de Patologia, Instituto de Ciências Biológicas, \\ Universidade de Passo Fundo, Passo Fundo, RS, Brasil
}

\begin{abstract}
Angiostrongylus costaricensis is a parasitic nematode of rodents and molluscs are the intermediate hosts. Nocturnal collection of molluscs and search for infective third stage larvae of A. costaricensis was carried out in 18 endemic foci identified by the notification of a confirmed diagnosis in human biopsies or surgical specimens. Molluscs were digested in acidic solution and isolation of larvae eventually present was done in a Baermann funnel. Larvae identified by the presence of a delicate groove in the tail were counted to assess the individual parasitic burden. Four species were found infected, with ranges of prevalence in parenthesis: Phyllocaulis variegatus (7\% to 33.3\%); Bradybaena similaris (11.7\% to 24.1\%); Belocaulus angustipes (8.3\%) and Phyllocaulis soleiformis (3.3\% to $14.2 \%$ ). Parasitic burden varied from 1 to 75 with $\mathrm{P}$. variegatus, 1 to 98 with $\mathrm{B}$. similaris, 1 to 13 with $\mathrm{B}$. angustipes and 1 larvae in each of two specimens of $\mathrm{P}$. soleiformis. P. variegatus was present in all sites and was found infected with the highest prevalence figures and the highest individual parasitic burdens. These data stress the importance of veronicellid slugs as intermediate hosts for A. costaricensis in the endemic areas in Rio Grande do Sul, Brazil.
\end{abstract}

Key words: Angiostrongylus costaricensis - abdominal angiostrongylosis - mollusc hosts - prevalence parasitic burden

Abdominal angiostrongylosis is a nematode infection caused by Angiostrongylus costaricensis Morera and Céspedes, 1971. Molluscs are involved in the cycle as intermediate hosts, producing the third stage larvae (L3), infective for the definitive host. The adult worm lives inside the mesenteric arteries in wild rodents, like Sigmodon hispidus in Central America and Oryzomys nigripes in southern Brazil (Morera 1973, Graeff-Teixeira et al. 1990). A new conception on the migration and maturation of this parasite in definitive hosts has recently been proposed by Mota and Lenzi (1995).

Human infection has been detected from Mexico to northern Argentina (Zavala-Velázquez et al. 1974, Demo \& Pessat 1986). In Brazil, the disease produced by A. costaricensis has been detected in the southern states, from the Distrito Federal (Brasília) to Rio Grande do Sul, RS, where a large number of diagnosis have been performed

Financial support: PUCRS, CNPq 500893/92-6, CAPES and FAPERGS

${ }^{+}$Corresponding author. Fax: +55-51-339.1511 (R 3148) Received 9 May 1996

Accepted 4 September 1996
(Graeff-Teixeira et al. 1991).

Although veronicellid slugs have been identified as hosts in several countries: Costa Rica (Morera \& Ash 1970), Ecuador (Morera et al. 1983), Honduras (Kaminsky et al. 1987, Morera et al. 1988), Brazil (Graeff-Teixeira et al. 1989a) and Nicaragua (Duarte et al. 1992), mollucs from other groups, like Limax maximus, may also have an important role as hosts for the parasite, in some foci (Graeff-Teixeira et al. 1993). Susceptibility was experimentally demonstrated for Biomphalaria glabrata, B. tenagophila, B. straminea, Sarasinula marginata and Megalobulimus abbreviatus (Graeff-Teixeira et al. 1989b, Lima et al. 1992a,b).

The objective of this paper is to report on prevalence and parasitic burden of A. costaricensis in molluscs collected in 18 foci of transmission of abdominal angiostrongylosis in southern Brazil.

\section{MATERIALS AND METHODS}

Nocturnal searches were undertaken in the surroundings of the houses of patients with histopathological diagnosis of abdominal angiostrongylosis, in RS - Brazil's southernmost state, from March 1993 to May 1995. The localization of the sites and the date of the expeditions are indicated in the Table I. 
All molluscs found on the surface of the soil nearby the house of patients were collected and kept in cotton bags containing vegetal debris, untill examination in the laboratory. For at least $1 \mathrm{hr}$ the area was scanned through continuous walking under the light of a $100 \mathrm{~W}$ gas lamp. An extended search for $2 \mathrm{hr}$ did not result in improved yield of molluscs, at sites where few specimens were collected. The cephalopodal mass of shelled molluscs or the eviscerated body of slugs were individually teased in a metal grid and incubated for $6 \mathrm{hr}$ in a $0.7 \%$ chloridric acidic solution, at room temperature, with occasional agitation (Graeff-Teixeira \& Morera 1995). Larvae eventually present were isolated with a Baermann funnel, identified and counted as metastrongylid larvae by the morphology of the tail.

\section{RESULTS}

In two sites no molluscs could be found: Erebango (Expedition number - EN 20) in a rural area and Tapejara (EN 10) at an urban area. In other 18 sites, the search for molluscs was successful (Table II). In Marau, collection was repeated in order to better evaluate a huge popula- tion of Bradybaena similaris and for this reason 19 is the total number of expeditions (see Table I).

Results of the search for metastrongylid larvae are presented in the Tables III and VI. In 11 sites (Table III) L3 was found in $P$. variegatus (Pv), $B$. similaris $(\mathrm{Bs}), P$. soleiforms $(\mathrm{Ps})$ and $B$. angustipes (Ba) with prevalences ranging from $7 \%$ to $33 \%$ for $\mathrm{Pv}, 11 \%$ to $24 \%$ for Bs, $3 \%$ to $14 \%$ for Ps and $8 \%$ for Ba. In Três de Maio the very small number of molluscs prevents evaluation of prevalence. Infection was not documented in Limax flavus, $L$. maximus, Deroceras sp. and Helix aspersa from several sites.

Taking as a working hypothesis the proposition that identification of infected molluscs is positively associated with a short time elapsed since the date of diagnosis of the index case and the date of expedition (data taken from Table I and ordenated in Table IV), the Yule coeficient was calculated for several different definitions of "short time interval", as shown in Table V. There were no indications of positive association.

The number of larvae found in individual molluscs is shown in Table VI. Without considering the species, only one L3 larvae was found in 20

TABLE I

Localities in Rio Grande do Sul, Brazil, where the search for molluscs infected with Angiostrongylus costaricensis was performed from March 1993 to May 1995, with indication of the date of histopathological diagnosis for every index case, patient initials, the time elapsed since the acute disease, and the date of expeditions

\begin{tabular}{|c|c|c|c|c|c|c|}
\hline Locality & Municipality & $\begin{array}{l}\text { Patient } \\
\text { initials }\end{array}$ & $\begin{array}{c}\text { Date of } \\
\text { diagnosis }\end{array}$ & $\begin{array}{l}\text { Time elapsed } \\
\text { in years } \\
\text { (months) }\end{array}$ & $\begin{array}{c}\text { Date of } \\
\text { expedition }\end{array}$ & $\begin{array}{c}\text { Expedition } \\
\text { number } \\
(\mathrm{EN})\end{array}$ \\
\hline \multirow[t]{2}{*}{ Marau } & \multirow[t]{2}{*}{ Marau } & \multirow[t]{2}{*}{ O.T. } & \multirow[t]{2}{*}{ Apr 81} & 14 & Jan 94 & 1 \\
\hline & & & & 13 & Apr $95^{a}$ & 2 \\
\hline Getúlio Vargas-IA $^{a}$ & Getúlio Vargas & I.A. & Apr 84 & 10 & Jan 94 & 3 \\
\hline Estação & Estação & E.V. & Mar 85 & 9 & Jan 94 & 4 \\
\hline Sta. Rosa-GM & Santa Rosa & G.M. & Jun 89 & 5 & May 94 & 5 \\
\hline Vila Petrópolis & Passo Fundo & D.L.V.L. & May 91 & 3 & Jan 94 & 6 \\
\hline S. Paulo Missões $b$ & S. Paulo Missões & A.P. & Ago 92 & 1 & Apr 93 & 7 \\
\hline Rodeio Bonito & Rodeio Bonito & S.A. & Nov 92 & 1 & Mar 93 & 8 \\
\hline Ametista do Sul & Ametista do Sul & G.Z.C. & Nov 92 & 1 & Apr 93 & 9 \\
\hline Tapejara & Tapejara & J.M. & Fev 93 & 1 & Jan 94 & 10 \\
\hline Sta. Rosa-Cruzeiro & Santa Rosa & Z.Z. & Feb 94 & $0(1)$ & Mar 94 & 11 \\
\hline Lajeado Manchinha $^{b}$ & Tuparendi & & & $0(1)$ & Mar 94 & 12 \\
\hline Tuparendi & Tuparendi & & & $0(1)$ & Mar 94 & 13 \\
\hline Colombo-Usina $^{b}$ & Guaporé & M.B. & Jul 94 & $0(2)$ & Out 94 & 14 \\
\hline Santa Bárbara & Santa Bárbara & E.H. & Jul 94 & $0(5)$ & Dec 94 & 15 \\
\hline B. Vista do Buricá & Boa Vista do Buricá & L.V.K. & Nov 94 & $0(6)$ & May 95 & 16 \\
\hline Pessegueiro $^{b}$ & Ernestina & S.P.B. & Jan 95 & $0(3)$ & Apr 95 & 17 \\
\hline Três de Maio & Três de Maio & L.S. & Jan 95 & $0(4)$ & May 95 & 18 \\
\hline Getúlio Vargas-DC ${ }^{a}$ & Getúlio Vargas & D.C. & Mar 95 & $0(1)$ & Apr 95 & 19 \\
\hline Erebango $^{b}$ & Erebango & & & $0(1)$ & Apr 95 & 20 \\
\hline Barreirinho & Sarandi & D.B. & Mar 95 & $0(1)$ & Apr 95 & 21 \\
\hline
\end{tabular}

$a$ : two expeditions were performed in the same site in Marau and two different sites were studied in the town of Getúlio Vargas; $b$ : rural areas. 


\section{TABLE II}

Distribution of mollusc species and number of individuals collected in 18 localities endemic for abdominal angiostrongylosis in Rio Grande do Sul (Brazil), from March 1993 to May 1995, corresponding to 19 expeditions since a site in Marau was visited twice

\begin{tabular}{|c|c|c|c|c|c|c|c|c|c|}
\hline Localities & Total & $\begin{array}{c}\text { Phylocaulis } \\
\text { variegatus }\end{array}$ & $\begin{array}{c}\text { Bradybaena } \\
\text { similaris }\end{array}$ & $\begin{array}{c}\text { Phyllocaulis } \\
\text { soleiformis }\end{array}$ & $\begin{array}{c}\text { Belocaulus } \\
\text { augustipes }\end{array}$ & $\begin{array}{l}\text { Limax } \\
\text { flavus }\end{array}$ & $\begin{array}{c}\text { Limax } \\
\text { maximus }\end{array}$ & $\begin{array}{c}\text { Helix } \\
\text { aspersa }\end{array}$ & $\begin{array}{c}\text { Deroceras } \\
\text { sp. }\end{array}$ \\
\hline Rodeio Bonito & 57 & 57 & - & - & - & - & - & - & - \\
\hline Ametista do Sul & 165 & 20 & 145 & - & - & - & - & - & - \\
\hline S. Paulo Missões ${ }^{a}$ & 6 & 6 & - & - & - & - & - & - & - \\
\hline Marau-Jan ${ }^{b}$ & 51 & 27 & 22 & - & - & - & 2 & - & - \\
\hline Marau-Apr ${ }^{b}$ & 91 & 6 & 85 & - & - & - & - & - & - \\
\hline Estação & 3 & 3 & - & - & - & - & - & - & - \\
\hline Getúlio Vargas-IA & 41 & 40 & - & - & - & - & 1 & - & - \\
\hline Getúlio Vargas-DC & 74 & 2 & 50 & - & 1 & 4 & 13 & 2 & 2 \\
\hline Vila Petrópolis & 7 & 7 & - & - & - & - & - & - & - \\
\hline Tuparendi & 53 & 53 & - & - & - & - & - & - & - \\
\hline Lajeado Manchinha $^{a}$ & 7 & 6 & - & - & 1 & - & - & - & - \\
\hline Sta. Rosa-GM & 46 & 8 & 11 & 7 & 12 & 2 & - & 6 & - \\
\hline Sta. Rosa-Cruzeiro & 88 & 27 & 60 & - & 1 & - & - & - & - \\
\hline Colombo-Usina $^{a}$ & 18 & 11 & - & - & - & 7 & - & - & - \\
\hline Santa Bárbara & 89 & 26 & - & 63 & - & - & - & - & - \\
\hline Pessegueiro $^{a}$ & 3 & 1 & - & - & - & - & - & - & 2 \\
\hline Barreirinho & 43 & 13 & - & 30 & - & - & - & - & - \\
\hline Três de Maio & 5 & 1 & 1 & - & 2 & 1 & - & - & - \\
\hline B. Vista do Buricá & 16 & 5 & - & - & 4 & 5 & - & - & 2 \\
\hline Total & 863 & 319 & 374 & 100 & 21 & 19 & 16 & 8 & 6 \\
\hline
\end{tabular}

$a$ : rural areas; $b$ : in Marau the study was repeated 14 months after the first collection.

TABLE III

Prevalence (\%, in parenthesis) of infection with third stage larvae of Angiostrongylus costaricensis, in molluscs collected in 18 endemic foci for abdominal angiostrongylosis, from March 1993 to May 1995,

in Rio Grande do Sul (Brazil)

\begin{tabular}{lcccc}
\hline Locality & $\begin{array}{c}\text { Phyllocaulis } \\
\text { variegatus }\end{array}$ & $\begin{array}{c}\text { Bradybaena } \\
\text { similaris }\end{array}$ & $\begin{array}{c}\text { Phyllocaulis } \\
\text { soleiformis }\end{array}$ & $\begin{array}{c}\text { Belocaulus } \\
\text { angustipes }\end{array}$ \\
\hline Rodeio Bonito & $13 / 57(22.8)$ & - & - & - \\
Ametista do Sul & $02 / 20(10.0)$ & $07 / 29(24.1)$ & - & - \\
Estação & $01 / 03(33.3)$ & - & - & - \\
Passo Fundo & $01 / 07(14.2)$ & - & - & - \\
Tuparandi & $04 / 53(07.0)$ & - & - & - \\
Sta. Rosa-GM & $01 / 08(12.5)$ & - & $01 / 07(14.2)$ & - \\
Sta. Rosa-Cruzeiro & $06 / 27(22.5)$ & $02 / 12(16.6)$ & - & - \\
Colombo-Usina & $01 / 11(09.0)$ & - & - & - \\
Barreirinho & - & $02 / 17(11.7)$ & - & $01 / 30(03.3)$ \\
Marau-Apr $a$ & - & $01 / 01$ & & 02 \\
Três de Maio & - & - &
\end{tabular}

$a$ : two expeditions were made to Marau; this one was performed in April 1995 (see Table I).

TABLE IV

Correlation between the time elapsed since the acute phase of the index case and results from parasitological examination in molluscs from 18 sites (19 expeditions) in Rio Grande do Sul (Brazil)

\begin{tabular}{lrrrrrrrrrrrrrrrrrrrr}
\hline Expeditions & $1^{a}$ & $2^{a}$ & 3 & 4 & 5 & 6 & 7 & 8 & 9 & 16 & 15 & 18 & 17 & 14 & 11 & 12 & 13 & 14 & 21 \\
Time (years) & 14 & 13 & 10 & 9 & 5 & 3 & 1 & 1 & 1 & 0 & 0 & 0 & 0 & 0 & 0 & 0 & 0 & 0 & 0 \\
$\quad$ (months) & & & & & & & & & & 6 & 5 & 4 & 3 & 2 & 1 & 1 & 1 & 1 & 1 \\
Parasitological & + & - & - & + & + & + & - & + & + & - & - & + & - & + & + & - & + & - & +
\end{tabular}

examination

a: two expeditions in a same site: Marau (see Table I); the expeditions, identified by numbers as defined in Table I, were arranged in a decrescent order of the variable "time". 


\section{TABLE V}

Estimation of Yule Coeficient ( $Q$ value) as a test of association between positive results in mollusc examination for Angiostrongylus costaricensis larvae and the time elapsed since the acute phase of the index case

\begin{tabular}{|c|c|c|c|}
\hline \multirow{2}{*}{$\begin{array}{l}\text { Several trials of grouping } \\
\text { the } 19 \text { sites according to } \\
\text { time elapsed since } \\
\text { acute phase (years) }\end{array}$} & \multicolumn{2}{|c|}{ Parasitological examination } & \multirow{2}{*}{$\begin{array}{c}\text { Q value } \\
\text { varies from -1 to } 1 \\
\text { (neg. to pos. association) } \\
\text { zero = no association }\end{array}$} \\
\hline & positive & negative & \\
\hline Upper limit of group “n” & $\mathrm{f}_{11}$ & $f_{12}$ & $f_{11} f_{22}-f_{21} f_{12}$ \\
\hline lower limit of group " $n+1$ " & $f_{21}$ & $f_{22}$ & $f_{11} f_{22}+f_{21} f_{12}$ \\
\hline$£ 0.5$ & 5 & 5 & -0.33 \\
\hline$>0.5$ & 6 & 3 & \\
\hline$£ 1$ & 7 & 6 & -0.26 \\
\hline$>1$ & 4 & 2 & \\
\hline$£ 3$ & 8 & 6 & -0.05 \\
\hline$>3$ & 3 & 2 & \\
\hline$£ 5$ & 9 & 6 & +0.20 \\
\hline$>5$ & 2 & 2 & \\
\hline$£ 9$ & 10 & 6 & +0.53 \\
\hline$>9$ & 1 & 2 & \\
\hline$£ 10$ & 10 & 7 & +0.17 \\
\hline$>10$ & 1 & 1 & \\
\hline
\end{tabular}

TABLE VI

Parasitic burden in molluscs found infected in 11 from 18 endemic foci of abdominal angiostrongylosis in Rio Grande do Sul (Brazil) is expressed as the absolute number of larvae isolated from individual molluscs

\begin{tabular}{ll}
\hline Mollusc species & Parasitic burden \\
\hline Phyllocaulis variegatus & $1,1,1,1,1,1,1,1,1,1,1,1,2,2,3,3,4,4,6,8,9,11,14,19,20,38,69,75$ \\
Bradybaena similaris & $1,1,1,1,1,2,2,2,3,5,13,98$ \\
Belocaulus angustipes & $1,2,13$ \\
$P$. soleiformis & 1,1 \\
\hline
\end{tabular}

TABLE VII

Comparison between the results of collection and examination of molluscs from Santa Rosa-GM, Rio Grande do Sul (Brazil), performed at different times. Results are presented as number of infected/total number collected, with prevalence $(\%)$ in parentesis

\begin{tabular}{|c|c|c|c|c|c|c|}
\hline \multirow{2}{*}{$\frac{\text { Mollusc species }}{\text { Bradybaena similaris }}$} & \multicolumn{2}{|c|}{$1992^{a}$} & \multicolumn{2}{|c|}{$1993^{b}$} & \multicolumn{2}{|c|}{$1994^{c}$} \\
\hline & $3 / 87$ & $(3.4)$ & $0 / 85$ & & $0 / 11$ & \\
\hline Helix aspersa & $0 / 33$ & & $3 / 63$ & $(4.7)$ & $0 / 06$ & \\
\hline Limax flavus & $1 / 42$ & $(2.8)$ & $0 / 07$ & & $0 / 02$ & \\
\hline Phyllocaulis variegatus & $3 / 27$ & (11.1) & $4 / 40$ & $(10.0)$ & $1 / 08$ & $(12.5)$ \\
\hline Phyllocaulis soleiformis & 0 & & $1 / 06$ & $(16.6)$ & $1 / 07$ & $(14.6)$ \\
\hline Belocaulus angustipes & $8 / 24$ & $(33.3)$ & $0 / 17$ & & $1 / 12$ & $(8.3)$ \\
\hline
\end{tabular}

$a$ : unpublished results; one specimen of Megalobulimus sp. was negative at examination and is not included in the table; $b$ : Thiengo et al. 1993; $c$ : present report.

out of $45(44 \%)$ examinations. The highest parasitic burden was 98 L3 in one specimen of $B$. similaris, but the highest proportion of values higher than $10 \mathrm{~L} 3 /$ mollusc was found in 7/28 (25\%) infected $P$. variegatus.

\section{DISCUSSION}

Slugs from the Veronicellidae family: Sarasinula plebeia (sin.= Vaginulus plebeius) in Central America and northern South America (Morera \& Ash 1970, Morera et al. 1983, Duarte 
et al. 1992), P. variegatus and B. angustipes from southern Brazil have been considered the important intermediate hosts of $A$. costaricensis (GraeffTeixeira et al. 1989a). Natural infection has also been documented in $P$. soleiformis (Thiengo et al. 1993).

The lack of a strict specificity of $A$. costaricensis for its intermediate host has been suggested by previous studies identifying as host several other molluscs, like L. maximus, L. flavus, B. similaris (Graeff-Teixeira et al. 1993) and $H$. aspersa (Thiengo et al. 1993). The absence of veronicellid slugs, especially in some rural areas where Megalobulimus abbreviatus and Epiphragmophora sp. could play the main role as hosts, is also an intriguing finding (Graeff-Teixeira et al. 1993). Two other metastrongylid worms, A. cantonensis and $A$. vasorum are also not very specific for intermediate hosts (Alicata 1965, Rosen et al. 1970).

$P$. variegatus was the most frequently collected and infected species, with prevalences ranging from $7 \%$ to $33.3 \%$, and it showed the highest parasitic burdens (Table VI). Very high prevalences, such as $75 \%$, are reported for Sarasinula plebeia in Costa Rica (Morera 1985) and maximum values of $7.6 \%$ in Honduras (Kaminsky et al. 1995) for the same species. Even without a proper standardization of the examination procedures, these variability appears to be real and may represent the diversity of transmission dinamics in different geographic areas.

Evaluation of individual parasitic burden in published studies of identification of intermediate hosts for A. costaricensis has not been described, despite its obvious epidemiological importance. Except for a very preliminar previous evaluation (unpublished results) in the same location of expedition number 5 (see Table I) there was no idea about what could be the parasitic burden in naturally infected molluscs. The results (Table VI) are somewhat surprising, since higher counts were expected. Even if we consider the problem that a satisfactory evaluation of sensitivity of the method used for detection of larvae is lacking, the counts are quite low.

If these data on larvae burden are confirmed in further evaluations, we could speculate that a low number of infective L3 is required to establish infection in vertebrate hosts, including man. These informations from natural infections should stimulate the improvement of experimental models, where high larvae inocula are employed in order to overcome methodological difficulties (Mota \& Lenzi 1995).

The discrete participation of $P$. soleiformis as host for $A$. costaricensis further illustrates the idea previously commented that documentation of sus- ceptibility in the laboratory does not define its epidemiological importance. This species has been employed for experimental infections for a long time (Graeff-Teixeira et al. 1989b) but in the endemic area in RS it occurs infrequently and it is seldom found infected.

The present data illustrate the importance of prevalence, parasitic burden and the size of the host's population in determination of epidemiological importance of a given host species. B. similaris usually occurs with very large populations, proliferating focally mainly in the vegetable gardens next to the houses. But individual larvae burden in this study was low, with 9 out of 12 specimens harboring less than 5 larvae. Examination of B. angustipes was only positive in two sites, with small numbers of infected snails and low parasitic burdens.

The estimation of Yule coeficient - $Q$ value (Table V) for several arrangements of the time elapsed since diagnosis of an index case (e.g. one group with equal or less than 0.5 year and other group with more than 0.5 year, etc.) resulted in low $\mathrm{Q}$ values and did not support the hypothesis of a positive association between "short time interval" and the identification of infected molluscs. Even without a statistical analysis, the endemicity of this parasitosis could be depicted in the analysis of distribution of positive results along time, as shown in Table IV. Data from Table IV also illustrates the pulsatile character of an enzootic focus: in the same site (Marau - EN 1) with a positive identification of infected slugs 14 years after the acute disease, in January 1994, the examination of molluscs was negative 14 months later, in April 1995 (EN 2).

Besides the diversity of species that may be found infected in different localities, some variability over time in the same site is also seen (Table VII). In Santa Rosa-GM site, there were two previous collections (one and two years before) showing oscillating prevalence figures specially for $B$. angustipes $(33.3 \%, 0 \%$ and $8.3 \%), H$. aspersa $(0 \%$, $4.7 \%$ and $0 \%$ ) but a regularity in prevalence with $P$. variegatus $(11.1 \%, 10 \%$ and $12.5 \%)$. This regularity may be another indicator for the importance of that mollusc species as host for A. costaricensis.

The data presented in the Table II was considered important to characterize the mollusc population in the studied sites, but they also contribute for the improvement in the knowledge of the geographic distribution of mollusc species in RS. As further studies better demonstrate mollusc species with well adapted relationship to $A$. costaricensis, the knowledge of its geographic distribution may help to map the human infection.

It is interesting to note the total number lower than 8 specimens of collected molluscs in three out 
of four rural sites (Table II). The description of the best environmental conditions for proliferation of "sinantropic" mollusc species is not the aim of the present report, but it is important to note the indications that neither the isolated rural human settlings nor the crowded urban areas are favorable for their proliferation. Most of the studied sites with large mollusc populations are urban areas with a rural-like environment: large gardens and even small crops' (corn, bean) cultivations. It is also noteworthy the occurrence of exotic species brought with european immigrants, like Limax sp., mainly in urban areas.

In conclusion, the observed prevalence and individual larvae burden in molluscs from 18 endemic foci in southern Brazil stress the importance of $P$. variegatus, as intermediate host for $A$. costaricensis.

\section{ACKNOWLEDGEMENTS}

To Dr Rubens Rodriguez and Carmen Maria Tagliari (Instituto de Patologia de Passo Fundo) for permanent support; to Eva Medeiros Floriano and Sarina Held (Parasitologia, Instituto de Biociências, PUCRS) for technical help.

\section{REFERENCES}

Alicata JE 1965. Biology and distribution of the rat lungworm, Angiostrongylus cantonensis, and its relationship to eosinophilic meningoencephalitis and other neurological disorders of man and animals. Adv Parasitol 3: 223-248.

Demo OJ, Pessat OAN 1986. Angiostrongilosis abdominal. Primer caso humano encontrado em Argentina. Prensa Médica Argentina 73: 732-738.

Duarte Z, Morera P, Davila P, Gantier JC 1992. Angiostrongylus costaricensis natural infection in Vaginulus plebeius in Nicaragua. Ann Parasitol Hum Comp 67: 94-96.

Graeff-Teixeira C, Avila-Pires FD, Machado RCC, Camillo-Coura L, Lenzi HL 1990. Identificação de roedores silvestres como hospedeiros do Angiostrongylus costaricensis no sul do Brasil. Rev Inst Med trop São Paulo 32: 147-150.

Graeff-Teixeira C, Camillo-Coura L, Lenzi HL 1989b. Suscetibilidade de Megalobulimus sp. à infecção por larvas de Angiostrongylus costaricensis. Anais do XI Congresso Brasileiro de Parasitologia, Rio de Janeiro, p. 151.

Graeff-Teixeira C, Camillo-Coura L, Lenzi HL 1991. Clinical and epidemiological studies on abdominal angiostrongyliasis in southern Brazil. Rev Inst Med trop São Paulo 33: 375-380.

Graeff-Teixeira C, Morera P 1995. Método para digestão de moluscos em ácido clorídrico para isolamento de larvas de metastrongilídeos. Biociências, PAlegre, 3: 85-89.

Graeff-Teixeira C, Thiengo SC, Thomé JW, Medeiros AB, Camillo-Coura L, Agostini AA 1993. On the diversity of mollusc intermediate hosts of Angiostrongylus costaricensis Morera \& Céspedes, 1971 in southern Brazil. Mem Inst Oswaldo Cruz. 88: 487-489.

Graeff-Teixeira C, Thomé JW, Pinto SCC, CamilloCoura L, Lenzi HL 1989a. Phyllocaulis variegatus - an intermediate host of Angiostrongylus costaricensis in south Brazil. Mem Inst Oswaldo Cruz 84: 65-68.

Kaminsky RG, Andrews K, Moran R 1987. Angiostrongylus costaricensis en babosa en Honduras. Estudio preliminar. Rev Med Hondur 55: 4-8.

Kaminsky RG, Caballero R, Andrews KL 1995. Presencia de Angiostrongylus costaricensis en Honduras y sus relaciones agro-ecologicas y humanas. Parasitol al Dia, Santiago, 19: 81-90.

Lima LC, Massara CL, Souza CP, Jannotti-Passos LK, Lenzi HL 1992a. Sarasinula marginata (Semper, 1885) (Mollusca, Soleolifera) de Belo Horizonte (MG, Brasil) como hospedeira intermediária potencial do Angiostrongylus costaricensis Morera e Céspedes, 1971. Rev Inst Med trop São Paulo 34: 117-120.

Lima LC, Massara CL, Souza CP, Vidigal TD, Lenzi HL, Carvalho OS 1992b. Suscetibilidade de planorbídeos da região metropolitana de Belo Horizonte, MG (Brasil) ao Angiostrongylus costaricensis (Nematoda, Angiostrongylidae). Rev Inst Med trop São Paulo 34: 399-402.

Morera P 1973. Life history and redescription of Angiostrongylus costaricensis Morera and Céspedes, 1971. Am J Trop Med Hyg 22: 613-621.

Morera P 1985. Angiostrongiliasis abdominal: transmission y observaciones sobre su posible control, p. 230235. In Control y erradicación de enfermedades infecciosas: un Simposio Internacional OMS/OPS. Série de Copublicaciones de la OPS, $\mathrm{n}^{\circ} 1$.

Morera P, Ash LR 1970. Investigación del huesped intermediário de Angiostrongylus costaricensis Morera y Céspedes, 1971. Bol Chileno Parasitol 25: 135 .

Morera P, Andrews KL, Rueda A 1988. The intermediate host of Angiostrongylus costaricensis in Honduras. Rev Biol Trop San José 36: 575-576.

Morera P, Lazo R, Urquizo J, Llaguno M 1983. First record of Angiostrongylus costaricensis Morera \& Céspedes, 1971 in Ecuador. Am J Trop Med Hyg 32: 1460-1461.

Mota ME, Lenzi HL 1995. Angiostrongylus costaricensis Life Cycle: a New Proposal. Mem Inst Oswaldo Cruz 90: 707-709.

Rosen L, Ash LR, Wallace GD 1970. Life history of the canine lungworm Angiostrongylus vasorum (Baillet, 1866). Am J Vet Res 31: 131-143.

Thiengo SC, Amato SB, Aventino A, Araújo JLB 1993. Estudo sobre os hospedeiros intermediários do Angiostrongylus costaricensis Morera \& Céspedes, 1971. Rev Bras Parasitol Vet 2 (Supl 1): 64.

Zavala-Velázques J, Ramírez-Baquedano W, ReyesPérez A, Bates-Flores M 1974. Angiostrongilosis costaricensis primeros casos mexicanos. Rev Invest Clín México 26: 389-394. 